$\begin{array}{ccc}\text { Tersedia online di: http://ejournal-balitbang.kkp.go.id/index.php/jppi } & \text { JURNAL } \\ \text { e-mail:jppi.puslitbangkan@ gmail.com } & \text { PENELITIAN } \\ \text { PERIKANAN } & \text { INDONESIA } \\ \text { JURNAL PENELITIANPERIKANANINDONESIA } & \text { Volume 26 Nomor 1 Maret 2020 } \\ \text { p-ISSN: 0853-5884 } & \text { e-ISSN: 2502-6542 } \\ \text { Nomor Akreditasi RISTEKDIKTI: 21/E/KPT/2018 }\end{array}$

\title{
STUDI DAYA DUKUNG SUMBER DAYA IKAN DI WADUK JATIBARANG SEMARANG
}

\section{STUDY ON CARRYING CAPACITY OF FISH RESOURCES IN JATIBARANG RESERVOIR, SEMARANG}

\author{
Aisyah $^{\star 1}$, Setiya Triharyuni ${ }^{1}$, Eko Prianto² dan Rudy Masuswo Purwoko \\ ${ }^{1}$ Pusat Riset Perikanan, Gedung. BRSDMKP II, JI. Pasir Putih 2, Ancol Timur, Jakarta Utara-14430, Indonesia \\ ${ }^{2}$ Dosen Fakultas Perikanan dan Kelautan, Simpang Baru, Kec. Tampan, Kota Pekanbaru, Riau-28292, Indonesia \\ Teregistrasi I tanggal: 21 Mei 2019; Diterima setelah perbaikan tanggal: 21 Oktober 2019; \\ Disetujui terbit tanggal: 31 Januari 2020
}

\begin{abstract}
ABSTRAK
Waduk Jatibarang merupakan waduk yang belum lama beroperasi dan masih tergolong waduk baru. Kegiatan perikanan yang berkembang didominasi oleh perikanan pancing. Selain penangkapan, peningkatan produksi juga dilakukan dengan penebaran ikan, namun belum didukung kajian daya dukung yang memadai. Penelitian ini dilakukan untuk mengetahui nilai daya dukung sumber daya ikan di waduk Jatibarang. Kegiatan penelitian dilakukan pada Bulan Mei dan Juli 2018 yang meliputi 4 (empat stasiun yang mewakili inlet, tengah dan outlet waduk. Data primer yang dikumpulkan meliputi kualitas air (parameter fisika, kimia dan biologi). Data pendukung penelitian meliputi elevasi muka air, diperoleh dari Balai Besar Wilayah Sungai Pemali-Juana, dan data kedalaman, diperoleh dari akuisisi data GPS Sounder. Hasil penelitian menunjukkan bahwa nilai daya dukung sumber daya ikan di Waduk Jatibarang berkisar antara 3,57-6,3 ton/ tahun. Kedalaman perairan sangat mempengaruhi nilai daya dukung. Nilai daya dukung lebih rendah pada kedalaman perairan lebih dari $20 \mathrm{~m}$ dan relatif tinggi pada kedalaman lebih dari 10 $\mathrm{m}$. Selain pengaruh kedalaman juga terdapat pengaruh lain seperti fluktuasi muka air, kelimpahan plankton, kecerahan, dan unsur hara berupa nitrat. Diharapkan kajian terkait potensi produksi dapat dilakukan untuk optimalisasi pemanfaatan perikanan yang berkelanjutan.
\end{abstract}

\section{Kata Kunci: Daya dukung; perikanan; kedalaman; klorofil-a; Waduk Jatibarang}

\begin{abstract}
Jatibarang Reservoir is a new operating reservoir. Existing fishing activities are dominated by handline. Except fishing activities, many fish have been stocked to improve the production, but it has not been supported by adequate carrying capacity studies. The purpose of this research was to determine the value of carrying capacity of fish resources in the Jatibarang Reservoir. The study was conducted in May and July 2018 representing the inlet, center, and outlet of the reservoir. The collected data consisted of physical, chemical, and biological data obtained at 4 (four) research stations representing the inlet, center, and outlet of the reservoir. Supporting data include water level elevation obtained from the Pemali-Juana River Basin Authority and bathymetry data obtained from GPS Sounder data acquisition. The results showed that the value of carrying capacity of fish resources in the Jatibarang Reservoir is 3.57-6.3 tons/year. The depth of the waters greatly affects the value of carrying capacity. The value of smaller carrying capacity occurs at the water depths of more than $20 \mathrm{~m}$, but is relatively high at the depths of more than $10 \mathrm{~m}$. There are also other influences such as water level fluctuations, plankton abundance, water brightness, and nitrates. Furthermore, a study of production potential should be carried out to optimize the sustainable fisheries utilization.
\end{abstract}

Keywords: Carrying capacity; fisheries; depth; chlorophyll-a; Jatibarang Reservoir 


\section{PENDAHULUAN}

Waduk atau bendungan Jatibarang terletak di Semarang, Jawa Tengah dan selesai dibangun tahun 2014. Waduk ini dibangun dengan membendung Sungai Kreo (anak Sungai Garang) yang terletak di Semarang Barat. Peruntukan waduk Jatibarang adalah untuk penyediaan air baku untuk wilayah Semarang bagian barat, pengendalian banjir kota Semarang, pembangkit tenaga listrik dan obyek pariwisata (PU, 2014). Di samping fungsi utama tersebut, terdapat pula aktivitas perikanan tangkap yang terkonsentrasi di sisi litoral waduk.

Penangkapan ikan yang diijinkan berkembang di Waduk Jatibarang adalah yang menggunakan alat tangkap pancing. Kegiatan pemancingan ikan di waduk Jatibarang tidak hanya dilakukan oleh masyarakat di sekitar waduk, akan tetapi juga berasal dari kota lain (Triharyuni et al., 2018). Kearifan lokal yang berkembang berupa batasan penggunaan alat tangkap lain selain pancing diduga berdampak pada kondisi sumber daya ikan yang berkelanjutan pada waduk ini. Sektor perikanan merupakan pendukung bagi fungsi wisata di Waduk Jatibarang, melalui keberadaan tempat-tempat makan di sisi darat waduk dan aktifitas pemancingan. Untuk mengoptimalkan pemanfaatan waduk, maka dilakukan penebaran ikan baik oleh masyarakat, instansi pemerintah baik daerah maupun pusat.

Penebaran ikan di Waduk Jatibarang memiliki intensitas yang relatif tinggi, sementara kajian mengenai daya dukungnya belum banyak dilakukan. Kajian daya dukung diperlukan untuk mengetahui daya atau kekuatan suatu perairan dalam menampung jumlah ikan tertentu pada lingkungan tertentu untuk dapat memenuhi kebutuhan populasi ikan tanpa menurunkan kualitas perairan (Byron et al., 2013;
Novita, 2015). Makalah ini membahas produktivitas primer dan daya dukung perikanan alami Waduk Jatibarang. Hasil kajian diharapkan menjadi bahan informasi dalam pengelolaan Waduk Jatibarang dari sisi ekosistem dan sumber daya ikan.

\section{BAHAN DAN METODE}

Penelitian dilakukan di Waduk Jatibarang, Kecamatan Gunungpati, Kota Semarang. Waduk Jatibarang memiliki luas daerah tangkapan air sebesar $54 \mathrm{~km}^{2}$, luas perairan 189 ha, debit rata-rata sebesar $2,9 \mathrm{~m}^{3} / \mathrm{dtk}$, tinggi muka air normal sebesar $148,9 \mathrm{~m}$ (Prima, 2018). Pada waduk ini terdapat masukan dari dua sungai yaitu Kreo dan Cebong (anak Sungai Kreo) sebagai inlet, dan Kreo sebagai outlet sebelum ke arah hilir hingga Pantai Utara Jawa.

Penelitian dilakukan tahun 2018 dengan dua kali pengambilan data di lapangan, yaitu Mei dan Juli 2018. Data yang dikumpulkan meliputi data primer dan data sekunder. Data primer terdiri dari data klorofil-a per strata kedalaman di 4 (empat) stasiun, data kedalaman melalui survei batimetri, parameter fisika perairan seperti kecerahan, parameter kimia seperti fosfat dan nitrat serta parameter biologi seperti kelimpahan plankton. Data sekunder yang diperoleh dari instansi setempat yang terkait dengan kajian ini, seperti fluktuasi muka air waduk dari Balai Besar Wilayah Sungai Pemali-Juana.

Lokasi pengambilan sampel dilakukan pada 4 (empat) stasiun yang mewakili semua lokasi waduk (Gambar 1), yaitu: inlet atau daerah saluran air masuk yang menghubungkan waduk dengan Sungai Kreo (stasiun 1), inlet atau daerah saluran air masuk yang menghubungkan waduk dengan Sungai Cebong (stasiun 2), outlet Waduk Jatibarang (stasiun 3) dan bagian tengah waduk (stasiun 4 ).

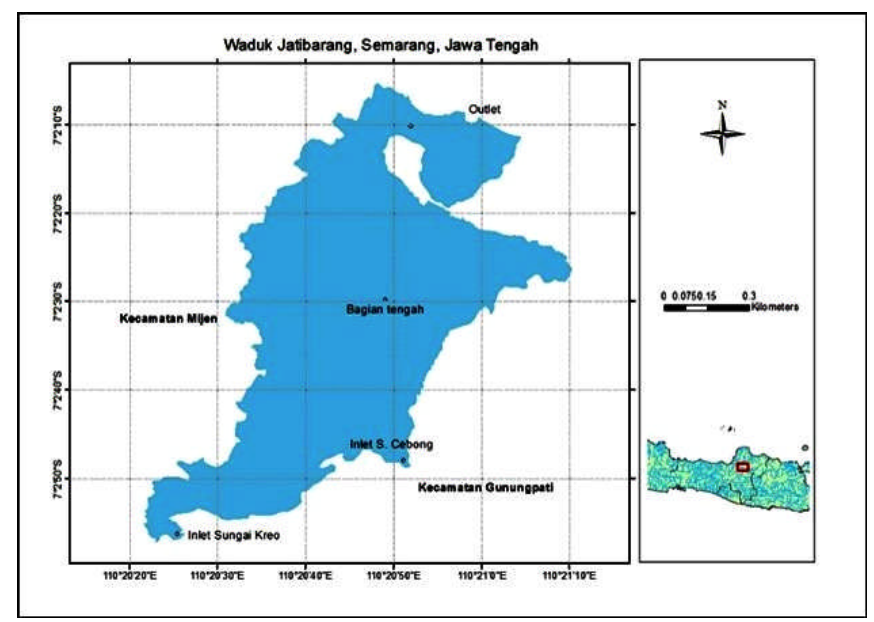

Gambar 1. Lokasi sampling di Waduk Jatibarang.

Figure 1. Sampling site in Jatibarang reservoir. 


\section{Analisis Produktivitas Primer}

Pengukuran produktivitas primer ditentukan melalui pendekatan kandungan klorofil-a (Smith, 2006) dengan persamaan:

$$
\sum P P=\frac{483 x C H L^{1,33}}{9+1,15 X C H L^{1,33}}
$$

dengan $P P$ adalah produktivitas primer $\left(\mathrm{gC} / \mathrm{m}^{2} /\right.$ th) dan $C H L$ adalah klorofil-a $\left(\mathrm{mg} / \mathrm{m}^{3}\right)$.

\section{Analisis Daya Dukung Perikanan}

Daya dukung perikanan dapat diketahui dengan pendekatan analisis kandungan produktivitas primer suatu perairan. Perhitungan daya dukung perikanan alami menggunakan pendekatan metode Beveridge (1987). Konversi nilai produksi primer ke dalam tabel Beveridge (1984) disajikan pada Tabel 1. Tabel ini merupakan hasil konversi kandungan karbon pada plankton menjadi karbon pada ikan, dimana diasumsikan bahwa kandungan karbon pada ikan segar adalah $10 \%$ dari berat basahnya.

Tabel 1. Konversi $\sum P P$ produksi ikan yang dapat dipanen pada perairan dengan produktivitas primer yang berbeda (Beveridge, 1984).

Table 1. $\quad \sum P P$ conversion of fish production that can be harvested in waters with different primary productivity (Beveridge, 1984).

\begin{tabular}{|c|c|}
\hline $\begin{array}{l}\sum P P\left(g C / m^{2} / \mathrm{th}\right) \\
\sum P P\left(g C / m^{2} / y r\right)\end{array}$ & $\begin{array}{l}\text { \% konversi ke ikan (g ikan C/m/th) } \\
\% \text { converted into Fish (g fish } \mathrm{C} / \mathrm{m} / \mathrm{yr} \text { ) }\end{array}$ \\
\hline$<1000$ & $1,0-1,2$ \\
\hline $1000-1500$ & $1,2-1,5$ \\
\hline $1500-2000$ & $1,5-2,1$ \\
\hline $2000-2500$ & $2,1-3,2$ \\
\hline $2500-3000$ & $3,2-2,1$ \\
\hline $3000-3500$ & $2,1-1,5$ \\
\hline $3500-4000$ & $1,5-1,2$ \\
\hline $4000-4500$ & $1,2-1,0$ \\
\hline$>4500$ & $<1,0$ \\
\hline
\end{tabular}

\section{HASIL DAN BAHASAN}

Hasil

\section{Produktivitas Primer Waduk Jatibarang}

Tinggi muka air (TMA) waduk pada rentang waktu pengamatan tahun 2016, 2017 dan 2018 menunjukan variasi sebagaimana dinamika pengaturan air waduk (BBWS Pemali Juana, 2016-2018). Kondisi TMA ratarata tahun 2016 adalah 148,6 m, tahun 2017 sebesar 148,8 m dan sebesar 149,7 pada tahun 2018 (data Januari-April) (Gambar 2).

Kedalaman waduk bervariasi, dengan kisaran 1,1$50,6 \mathrm{~m}$ dengan rata-rata $16,9 \mathrm{~m}$. Bagian tengah hingga sekitar outlet/bendungan (sisi utara waduk) merupakan yang terdalam dengan kedalaman lebih besar dari $20 \mathrm{~m}$, kondisi kedalaman inlet dalam kategori sedang antara 10-13 m, sementara litoral merupakan bagian yang dangkal dengan kedalaman kurang dari $10 \mathrm{~m}$ (Gambar 3).

Kecerahan perairan berada pada kisaran $66-80 \mathrm{~cm}$. Kecerahan yang lebih rendah dijumpai pada bagian inlet Sungai Kreo dibandingkan dengan bagian lain dari waduk. Nilai kecerahan lebih tinggi pada pengamatan Juli 2018 dari pada Mei 2018. Kandungan nitrat berada pada kisaran $<0,1-0,6 \mathrm{mg} / \mathrm{L}$. Pengamatan Mei 2018 menunjukan konsentrasi nitrat yang merata dan kecil yaitu $<0,1 \mathrm{mg} / \mathrm{L}$. Pengamatan Juli 2018 menunjukan nilai konsentrasi nitrat yang lebih tinggi secara signifikan yaitu 0,5-0,6 mg/L. Konsentrasi fosfat berada pada kisaran $0-7,76 \mathrm{mg} / \mathrm{L}$, sama halnya dengan kondisi nitrat, fosfat pada pengamatan Juli 2018 memiliki kadar yang tinggi. Kelimpahan plankton pada pengamatan tahun 2018 berada pada kisaran 5.733,33-150.333,33 ind./L. Secara spasial kelimpahan tertinggi terjadi pada bagian inlet waduk dan terendah pada outlet. 


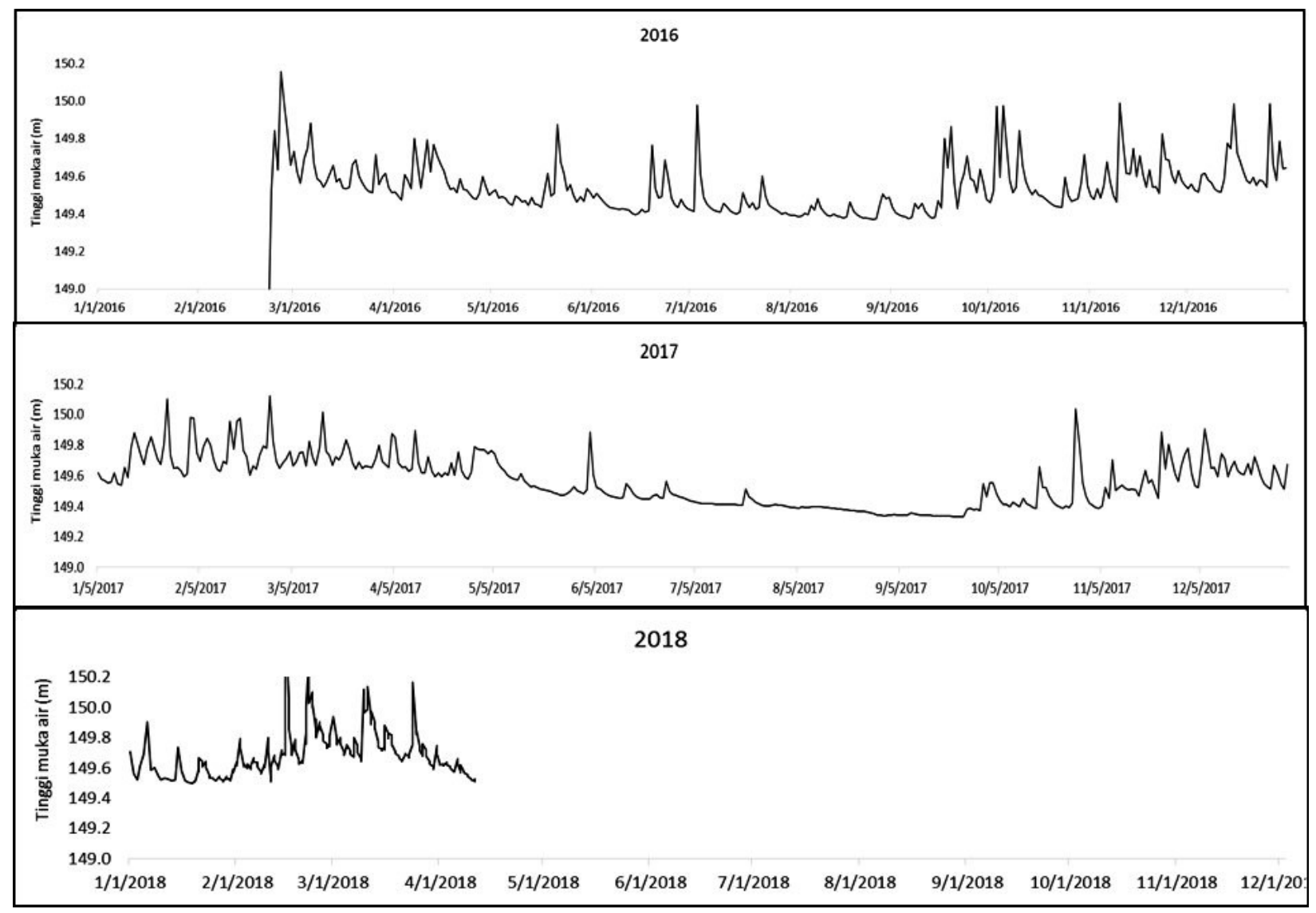

Gambar 2. Fluktuasi muka air di Waduk Jatibarang 2016 - April 2018 (Mei-Desember 2018 tidak ada data).

Figure 2. Water level fluctuation of Jatibarang Reservoir in 2016-April 2018 (There is no data in periode of May-December 2018).

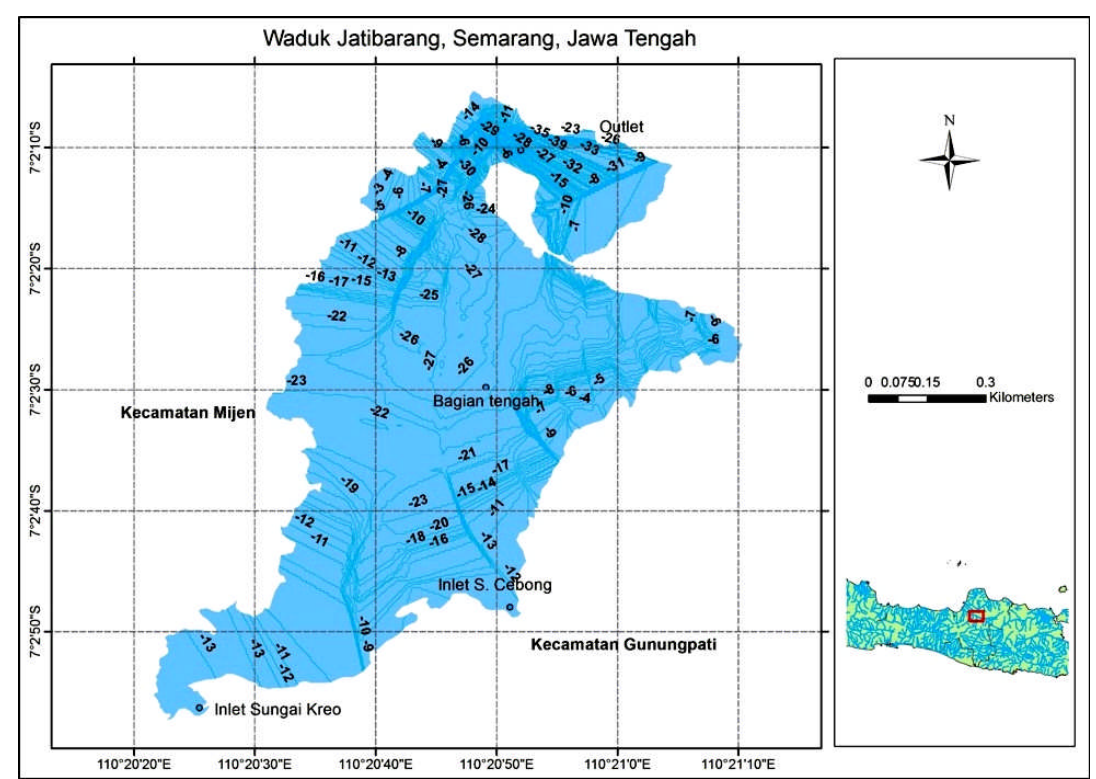

Gambar 3. Kedalaman Waduk Jatibarang, akuisisi data Mei 2018.

Figure 3. Depth of Jatibarang Reservoir, data acquisition in May 2018. 
Hasil pengukuran konsentrasi klorofil-a selama penelitian di Waduk Jatibarang menunjukan kisaran nilai 0,603-2,734 dengan nilai tertinggi sebesar 5,050 $\mu \mathrm{g} / \mathrm{L}$ pada kolom perairan bagian inlet. Konsentrasi klorofil-a yang relatif tinggi selalu terjadi pada permukaan, kecuali pada stasiun 1 (bagian inlet
Sungai Kreo). Konsentrasi klorofil-a di Waduk Jatibarang secara vertikal selama penelitian disajikan pada Gambar 4. Secara umum konsentrasi klorofil-a menurun seiring dengan bertambahnya kedalaman, kecuali pada stasiun 1 yang mengalami peningkatan pada bagian kolom perairan.

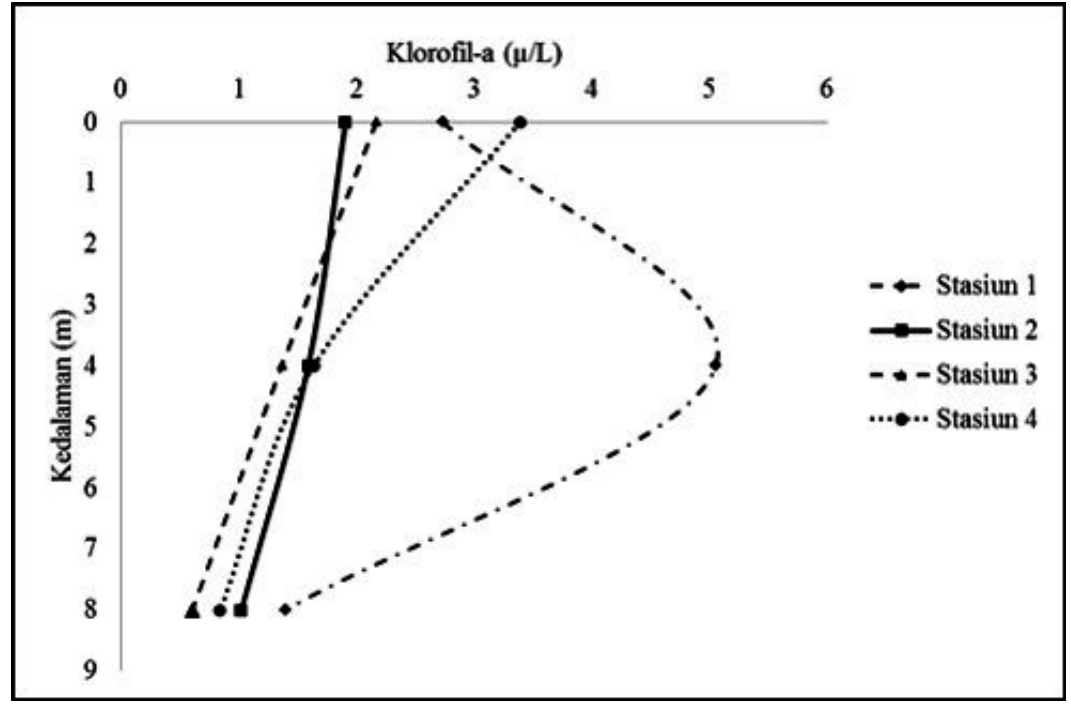

Gambar 4. Profil konsentrasi klorofil-a di Waduk Jatibarang.

Figure 4. Profile of chlorophyll-a concentration in Jatibarang Reservoir.

Rata-rata konsentrasi klorofil-a di Waduk Jatibarang berbeda-beda sesuai kedalaman waduk, yaitu $1,73 \mathrm{mg} / \mathrm{L}$ pada kedalaman $<10 \mathrm{~m}, 2,28 \mathrm{mg} / \mathrm{L}$ pada kedalaman $10-<20 \mathrm{~m}, 1,66 \mathrm{mg} / \mathrm{L}$ pada kedalaman > $20 \mathrm{~m}$. Dengan variasi nilai tersebut maka diperoleh nilai produktivitas primer berturut-berturut sebesar $87,81 \mathrm{gC} / \mathrm{m}^{2} /$ tahun, $116,24 \mathrm{gC} / \mathrm{m}^{2} /$ tahun, $84,44 \mathrm{gC} / \mathrm{m}^{2} /$ tahun (Tabel 2).

\section{Daya Dukung Waduk Jatibarang}

Sebagaimana produktivitas primer, nilai daya dukung sumber daya ikan di Waduk Jatibarang dibedakan kedalam tiga strata kedalaman, yaitu i) kedalaman kurang dari $10 \mathrm{~m}$, ii) antara 10-20 m dan iii) lebih besar dari $20 \mathrm{~m}$. Nilai daya dukung yang diperoleh berkisar antara 3,57-6,3 ton/tahun, dengan daya dukung terbesar berada pada kedalaman antar 10-20 m, kemudian kedalaman kurang dari $10 \mathrm{~m}$ dan yang terendah pada kedalaman lebih dari $20 \mathrm{~m}$ (Tabel 2).

Tabel 2. Parameter perhitungan daya dukung perikanan alami waduk Jatibarang.

Table 2. Calculation of natural fisheries carrying capacity of Jatibarang reservoir.

\begin{tabular}{|c|c|c|c|c|}
\hline $\begin{array}{l}\text { Parameter } \\
\text { Parameters } \\
\end{array}$ & $\begin{array}{l}\text { Satuan } \\
\text { Unit }\end{array}$ & $\begin{array}{l}\text { Nilai }{ }^{*} \\
\text { Value }\end{array}$ & $\begin{array}{l}\left.\text { Nilai }{ }^{* *}\right) \\
\text { Value }\end{array}$ & $\begin{array}{c}\text { Nilai }^{* * *} \\
\text { Value }\end{array}$ \\
\hline Klorofil & $\mathrm{mg} / \mathrm{m}^{3}$ & 1,73 & 2,28 & 1,66 \\
\hline Produktivitas primer & $\mathrm{gC} / \mathrm{m}^{2} /$ tahun & 87,81 & 116,24 & 84,44 \\
\hline $\begin{array}{l}\text { Konversi produktivitas } \\
\text { ikan/tahun }\end{array}$ & gen & 0,80 & 0,80 & 0,80 \\
\hline Produksi ikan & 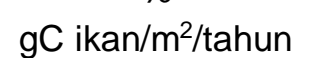 & 70,25 & 92,99 & 67,55 \\
\hline Daya dukung & ton/tahun & 47,80 & 63,27 & 35,75 \\
\hline Asumsi $10 \%$ dari berat basah & ton/tahun & 4,78 & 6,3 & 3,57 \\
\hline
\end{tabular}

Ket. : $\left.{ }^{\star}\right)$ kedalaman $\left.<10 \mathrm{~m} ;{ }^{\star *}\right)$ kedalaman $\left.10-<20 \mathrm{~m} ;{ }^{* \star *}\right)$ kedalaman $>20 \mathrm{~m}$ 


\section{BAHASAN}

Variasi tinggi muka air periode 2016 - 2018 menunjukan bahwa muka air rendah yang ekstrim terjadi pada Januari-Maret 2016. Hal tersebut diduga karena curah hujan yang rendah. Curah hujan dengan intensitas ringan sampai sedang terjadi hingga bulan April 2016 karena efek monsoon Australia dan terjadinya ELNINO (LAPANa ${ }^{2}$ 2017). Sementara tinggi muka air pada tahun 2017 lebih fluktuatif, yaitu tinggi di awal tahun, pertengahan tahun menurun lalu naik dari awal Oktober hingga akhir tahun. Hal tersebut seiring dengan musim basah yang terjadi di Jawa karena pengaruh aktivitas monsoon Asia yang dominan di awal dan menjelang akhir tahun (LAPAN ${ }^{b}, 2017$ ). Selanjutnya pada Januari-April 2018 menunjukkan kondisi muka air yang tinggi yang disebabkan oleh tingginya tingkat curah hujan karena musim di Indonesia memasuki fase basah hingga transisi musim basah ke kering (LAPAN ${ }^{c}$, 2017). Tinggi muka air baik di perairan waduk maupun danau mempengaruhi masukan dan keluaran nutrien yang secara tidak langsung berkaitan dengan daya dukung perairan (Coops et al., 2003; Wang et al., 2012).

Kecerahan merupakan ukuran transparansi suatu perairan, nilai kecerahan berpengaruh pada interaksi organisme dalam perairan (Goldman \& Horne, 1983). Nilai kecerahan perairan Waduk Jatibarang menunjukan nilai rendah pada bagian inlet Sungai Kreo dibandingkan dengan bagian lain dari waduk. Inlet merupakan bagian yang mengalami percampuran massa air antara air yang masuk dengan yang ada di waduk dengan membawa karakteristik tertentu dari air (Wetzel, 2001). Jika dibandingkan antara periode 2016-2018, kisaran nilai kecerahan yang rendah terjadi pada tahun $2017(21-77,5 \mathrm{~cm})$ (Susanti, 2017; Silitonga, 2017; Faizin, 2018) karena terjadi fluktuasi muka air dalam periode pendek (fluktuatif dan dinamis).

Hasil pengukuran konsentrasi nitrat dan fosfat selama penelitian di perairan waduk Jatibarang berkisar antara $<0,1-0,6 \mathrm{mg} / \mathrm{L}$ dan 0-7,76 mg/L. Nilai tersebut tergolong rendah dan masih memenuhi baku mutu perairan (PP 82 Tahun 2001). Selanjutnya hasil pengukuran secara spasial menunjukkan bahwa kelimpahan fitoplankton dan klorofil tertinggi terjadi pada outlet, yang menunjukan adanya keselarasan antara nilai klorofil dan kelimpahan fitoplankton. Hal tersebut sesuai dengan Parsons et al. (1984) dan Arinardi (1996) yang menyatakan bahwa kandungan klorofil di perairan berhubungan erat dengan kelimpahan fitoplankton di dalamnya.
Nilai klorofil waduk Jatibarang cenderung tinggi, yaitu mencapai $5,050 \mu \mathrm{g} / \mathrm{L}$. Nilai ini serupa dengan hasil pengamatan 2017 (Silitonga, 2017; Faizin, 2018), dengan masing-masing kisaran 0,309-5,93 mg/L dan $0,603-5,505 \mathrm{mg} / \mathrm{L}$. Berbeda halnya dengan hasil pengukuran pada 2016 yang menunjukkan nilai klorofil yang rendah, yaitu 0,069-1,760 mg/L (Rohmah et al., 2016; Wening, 2016). Tingginya nilai klorofil pada 2017 dan 2018 diduga karena fluktuasi muka air yang cenderung stabil. Pengamatan pada 2017 dilakukan pada saat kondisi muka air stabil tinggi di periode Juni, September dan November. Demikian pula dengan tahun 2018, pengamatan dilakukan pada saat kondisi muka air stabil rendah di periode Mei dan Juli. Sementara itu, pada tahun 2016, pengamatan dilakukan pada saat kondisi muka air berfluktuatif, yaitu fase rendah pada periode bulan Januari-Maret dan fase air mulai tinggi pada bulan April-Mei. Pada saat kondisi air dalam kondisi stabil, maka masa tinggal air berada pada periode panjang, sehingga diduga plankton memiliki waktu berkembang (Gomes \& Miranda, 2001). Perkembangan tersebut jika dikaitkan dengan parameter kualitas air lainnya, akan mempengaruhi produktivitas primer dan berdampak pada nilai klorofil-a suatu perairan (Carneiro et al., 2014).

Secara umum profil menegak klorofil-a menunjukan bahwa konsentrasi tinggi terjadi pada permukaan perairan dan menurun seiring bertambahnya kedalaman(Indriani et al., 2016; Haryanto, 2012; Asriyana \& Yuliana, 2007). Tingginya nilai klorofil-a di permukaan dikarenakan tingginya intensitas cahaya matahari yang masuk ke perairan. Sejalan dengan bertambahnya kedalaman, intensitas matahari yang masuk ke perairan semakin berkurang sehingga klorofil-a juga berkurang. Kondisi demikian selaras dengan hasil pengamatan, dimana konsentrasi nilai klorofil yang relatif tinggi terjadi di permukaan perairan waduk, kecuali pada stasiun 1 (inlet Sungai Kreo) di kolom perairan (kedalaman $4 \mathrm{~m}$ ). masih tingginya nilai klorofil-a sampai pada kedalaman $4 \mathrm{~m}$ disebabkan oleh masih terjangkaunya sinar matahari hingga kedalaman tersebut karena nilai kecerahan perairan teramati hingga $60 \mathrm{~cm}$ dari permukaan.

Produktivitas primer suatu perairan adalah gambaran aliran energi yang mengalir dalam suatu perairan melalui proses fotosintesis, yang mana cahaya, suhu, nitrogen dan fosfor merupakan faktorfaktor yang mempengaruhi (Odum, 1995; Wetzel, 2001; Romimohtarto, 2007). Produktifitas primer merupakan fungsi dari klorofil-a dengan hubungan klorofil dan produktifitas primer bersifat linear positif (Nuzapril et al., 2017). Semakin tinggi nilai klorofil-a 
maka semakin tinggi juga nilai produktifitas primernya. Hubungan kedalaman dan klorofil-a berkorelasi negatif, sehingga produktifitas primer juga memiliki korelasi yang bersifat negatif dengan kedalaman, atau dengan kata lain semakin dalam suatu perairan maka nilai produktifitas primernya semakin menurun. Hal ini seperti kajian yang dihasilkan oleh Rohmah et al. (2016) yang menyatakan bahwa hubungan kedalaman dan produktifitas primer dengan uji regresi diperoleh hubungan yang negatif.

Daya dukung dapat diartikan sebagai kemampuan atau kapasitas ekosistem dalam menampung produksi maksimum dari suatu spesies atau populasi (Toda et al., 2004; Legoviæ et al., 2008). Hal yang sama dinyatakan dalam Kenchington dan Hudson (1988), dengan aspek-aspek yang mempengaruhi daya dukung tersebut, yaitu waktu pembilasan (flushing time), volume badan air serta beban limbah yang masuk ke perairan. Salah satu jenis daya dukung adalah daya dukung produksi (production carrying capacity) (Inglis et al., 2002; McKindsey et al., 2006). Daya dukung produksi merupakan tingkat produksi optimal dari suatu spesies target dimana daya dukung ini tergantung kepada daya dukung fisik yang merupakan fungsi dari produktivitas primer (Legovic et al., 2008; McKindsey et al., 2006).

Nilai daya dukung perairan Waduk Jatibarang berada pada kisaran 3,57-6,3 ton/tahun. Nilai ini memiliki arti kemampuan optimum perikanan tangkap saat ini dalam memproduksi ikan. Nilai tersebut lebih kecil dibandingkan dengan nilai dari daya dukung waduk lain, yaitu Waduk Sempor 51,83 ton/tahun (Sholeh, 2015) dan Danau Tajwid 6,925 ton/tahun (Fadilah, 2018). Akan tetapi lebih tinggi dibandingkan dengan Situ Cilala 3,51 ton/tahun (Novita et al., 2015) dan Danau Tanjung Putus 1,74 ton/tahun (Laia et al, 2018). Tinggi rendahnya nilai daya dukung perikanan alami disebabkan oleh luasan waduk dan juga nilai klorofil-a perairan. Sebagaimana yang dinyatakan dalam Laia et al. (2018), bahwa luas perairan dan konsentrasi klorofil-a mempengaruhi nilai daya dukung. Luasan waduk dan konsentrasi klorofil-a tiap perairan tersebut tersaji dalam Tabel 3.

Tabel 3. Luasan dan nilai klorofil-a beberapa waduk/danau di Indonesia.

Table 3. Areas and chlorophyll-a in several reservoirs / lakes in Indonesia.

\begin{tabular}{lccl}
\hline $\begin{array}{c}\text { Waduk/Danau } \\
\text { Reservoir/Lake }\end{array}$ & $\begin{array}{c}\text { Luas area (ha) } \\
\text { Width }(\mathbf{h a})\end{array}$ & $\begin{array}{c}\text { Klorofil-a }\left(\mathbf{m g} / \mathbf{m}^{\mathbf{3}}\right) \\
\text { Chlorophyll-a }\left(\mathbf{m g} / \mathbf{m}^{3}\right)\end{array}$ & $\begin{array}{l}\text { Pustaka } \\
\text { References }\end{array}$ \\
\hline Waduk Jatibarang & 189 & $1,66-2,28$ & Penelitian ini \\
Waduk Sempor & 275 & 25 & Sholeh, 2015 \\
Situ Cilala & $12^{*}$ & $25^{\star *}$ & Novita2013; ${ }^{* *}$ Novita et al., \\
& 5 & 7,317 & 2015 \\
Danau Tanjung Putus & 22,5 & 8,76 & Laia et al, 2018 \\
Danau Tajwid & & Fadilah, 2018 \\
\hline
\end{tabular}

\section{KESIMPULAN}

Nilai daya dukung sumber daya ikan Waduk Jatibarang berkisar antara 3,57-6,3 ton/tahun. Nilai tersebut dipengaruhi oleh produktivitas primer yang dipengaruhi oleh kedalaman perairan, fluktuasi muka air, kelimpahan plankton, kecerahan dan unsur hara berupa nitrat. Nilai daya dukung lebih kecil terjadi pada kedalaman perairan lebih dari $20 \mathrm{~m}$, dan relatif tinggi pada kedalaman lebih dari $10 \mathrm{~m}$. Nilai daya dukung dalam kajian ini tidak dipengaruhi oleh luasan perairan. Penelitian selanjutnya diharapkan dapat mengkaji nilai potensi produksi dan status perikanan untuk mengoptimalkan upaya pengelolaan perikanan yang tepat dan berkelanjutan.

\section{PERSANTUNAN}

Paper merupakan bagian dari penelitian Dampak Penebaran Ikan terhadap Sumber Daya Ikan di Wilayah Pengelolaan Perikanan Perairan Daratan
(WPP PD) 434 di Pusat Riset Perikanan tahun anggaran 2018. Ucapan terima kasih kami sampaikan kepada Prof. Dr. Husnah, M.Phill sebagai ketua kelompok penelitian atas arahan selama penelitian berlangsung. Kontributor utama pada tulisan ini adalah Aisyah dan Setiya Triharyuni.

\section{DAFTAR PUSTAKA}

Arinardi, (1996). Kisaran kelimpahan dan komposisi plankton predominan di Perairan Kawasan Tengah Indonesia. LIPI. Bogor. $94 \mathrm{hlm}$.

BBWS Pemali Juana. (2018). Series data tinggi muka air dalam bentuk file dari tahun 2016-2018. Balai Besar Wilayah Sungai Pemali Juana, Kota Semarang.

Beveridge, M.C.M., (1984). Cage and pen fish farming . Carrying capacity models and environmental impact. FAO Fish.Tech.Pap., (255) : 131 p. 
Beveridge MCM. (1987). Cage aquaculture. England. Fishing News Books Ltd.

Byron, C.J., \& Costa-Pierce, B.A. (2013). Carrying capacity tools for use in the implementationof an ecosystems approach to aquaculture. In L.G. Ross, T.C. Telfer, L. Falconer, D. Soto\& J. AguilarManjarrez, eds. Site selection and carrying capacities for inland and coastalaquaculture (pp. 87101). FAO Fisheries and Aquaculture Proceedings No. 21. Rome, FAO. 282 pp.

Coops, H., Beklioglu, M., \& Crisman, T.L. (2003). The role of water-level fluctuations in shallow lake ecosystems-workshop conclusions. Hydrobiologia, 506(1): 23-7. DOI: 10.1023/ B:HYDR.0000008595.14393.77.

Fadilah, N.W.S. (2018). Daya dukung perikanan alami berdasarkan klorofil-a di danau tajwid kecamatan langgam Kabupaten Pelalawan Provinsi Riau. Jurnal Fakultas perikanan dan Kelautan, Universitas Riau, Pekanbaru: 9hlm.

Faizin, K.A. (2018). Profil status kesuburan perairan secara vertical di Waduk Jatibarang, Semarang. Skripsi. Fakultas Perikanan dan IImu Kelautan, Universitas Diponegoro. $90 \mathrm{hlm}$.

Goldman, G.R., \& Horne, A.J. (1983). Limnology. United States of America: McGraw Hill Book Company. $464 \mathrm{p}$

Indriani, W. (2016). Status trofik perairan berdasarkan nitrat, fosfat, dan klorofil-a di Waduk Jatibarang. Skripsi. Fakultas Perikanan dan Ilmu Kelautan, Universitas Diponegoro. $52 \mathrm{hlm}$

Inglis, G.J., Hayden, B.J., \& Ross, A.H. (2002). An overview of factors affecting the carrying capacity of coastal embayments for mussel culture. NIWA, Christchurch. Client Report CHC00/69: vi+31 pp.

Kenchington, RA \& Hudson BET. (1988). Coral reef management handbook. Unesco Regional Office for Science and Technology for South-East Asia.Jakarta.32 $1 \mathrm{p}$.

LAPANa.(2017).http://psta.lapan.go.id/index.php/ subblog/read/2016/189/Anomali-Basah-di-MusimPeralihan-Variabilitas-Iklim-Bulan-Mei-2016/ variabilitas-iklim-indonesia, diakses pada $16 \mathrm{Mei}$ 2019.

LAPAN ${ }^{b}$. (2017). http://psta.lapan.go.id/index.php/ subblog/read/2017/257/Kondisi-Atmosfer-Pada-
Bulan-Januari-2017/variabilitas-iklim-indonesia, diakses pada 16 Mei 2019.

LAPANc.(2017).http://psta.lapan.go.id/index.php/ subblog/read/2018/351/VARIABILITAS-IKLIMAPRIL-2018/variabilitas-iklim-indonesia, diakses pada 16 Mei 2019.

Legoviæ T, Palerud R, Christensen G, White P,Regpala R. (2008). A model to estimate aquaculturecarrying capacity in three areas of the Philippines.Science Diliman. 20(2): 31-40.

McKindsey, C.W., Thetmeyer, H., Landry, T. \& Silvert, W. (2006). Review of recentcarrying capacity models for bivalve culture and recommendations for research andmanagement. Aquaculture, 261(2): 451-462. doi:10.1016/j.aquaculture.2006.06.044

Novita M.Z., K. Soewardi \& N.T.M. Pratiwi. (2015). Penentuan Daya Dukung Perairan untuk Perikanan Alami (Studi Kasus: Situ Cilala, Kabupaten Bogor). Jurnal IImu Pertanian Indonesia (JIPI) Vol. 20 (1): 66 71. https://journal.ipb.ac.id/index.php/ $\mathrm{JIPl} /$ article/view/9295

Nuzapril, M., S.B. Susilo \& J. P. Panjaitan. (2017). Hubungan antara konsentrasi klorofil-a dengan tingkat produktivitas primer menggunakan citra satelit landsat-8. Jurnal Teknologi Perikanan dan Kelautan Vol. 8 No. 1 Mei 2017: 105-114. DOI: https://doi.org/10.24319/jtpk.8.105-114.

Odum, P. (1995). Dasar-Dasar Ekologi (Terjemahan).Yogyakarta: Gadjah Mada University Press. $697 \mathrm{hlm}$

Peraturan Pemerintah Republik IndonesiaNomor 82 Tahun 2001 Tentang Pengelolaan Kualitas Air dan Pengendalian Pencemaran Air.

Parsons, T. R., M. Takeshi, dan B. Hagrave. (1977). Biological oceanographic process. Second edition. Oxford. Pergamon press. Great Britain. 332p.

Prima, A.R. (2018). Konstruksi bendungan Jatibarang Kota Semarang. Engineer Weekly. $5 \mathrm{hlm}$

Rohmah, W.S., Suryanti \& M.R. Muskananfola. (2016). Pengaruh kedalaman terhadap nilai produktivitas primer di Waduk Jatibarang Semarang. DIPONEGORO JOURNAL OF MAQUARES, vol. 5 (3) : 150-156. https:// ejournal3.undip.ac.id/index.php/maquares/index. 
Silitonga, Y.T.E. (2017). Peranan tata guna lahan bagian hulu terhadap tingkat kesuburan perairan pada Waduk Jatibarang, Semarang. Skripsi. Fakultas Perikanan dan IImu Kelautan, Universitas Diponegoro. $67 \mathrm{hlm}$

Smith, V.H. (2007). Using Primary Productivity As an Index of Coastal Eutrphication: the Units of Measurement Matter. Journal of Plankton Research, 29(1) : 1-6. https://doi.org/10.1093/plankt/fbl061

Susanti, R. (2017). Kondisi kualitas air Waduk Jatibarang ditinjau dari aspek saprobitas perairan. Skripsi. Fakultas Perikanan dan IImu Kelautan, Universitas Diponegoro. $109 \mathrm{hlm}$
Toda, S. Matsuda, O. \& Yamasaki, M. (2004). Ecosystem and Carrying capacites of Aquaculture ground for sustainable development of aquaculture and stock enhancement. Seikai National Fisheries Resereach Institute. NAGASAKI 2-3 November 2004. Bull. Fish. Res. Agen. No. 19, 1-7, 2007

Wang, F., Wang, X., Zhao, Y. Yang, Z. (2012). Longterm changes of water level associated with chlorophyll a concentration in Lake Baiyangdian, North China. Procedia Environmental Sciences, 13 (2012) : 1227-1237. https://doi.org/10.1016/ j.proenv.2012.01.116

Wetzel, R.G. (2001). Limnology lake and river ecosystems. $3^{\text {rd }}$ Edition. Academic Press, 1006 pp. 